\title{
Perceived Ease of Use, Perceived Usefulness, Perceived Security and Intention to Use E-Filing: The Role of Technology Readiness*
}

\author{
Afrizal TAHAR ${ }^{1}$, Hosam Alden RIYADH ${ }^{2}$, Hafiez SOFYANI ${ }^{3}$, Wahyu Eko PURNOMO ${ }^{4}$
}

Received: June 28, 2020 Revised: July 12, 2020 Accepted: August 10, 2020

\begin{abstract}
This study aimed to analyze evidence of the effect of perceived ease-of-use, perceived usefulness, and perceived security on the citizen's intention to use e-Filing with information technology readiness as an intervening variable. This study used primary data collected from Civil Servants Taxpayers, Indonesian National Armed Forces, and State Police of the Republic of Indonesia in Semarang City. One hundred fifty questionnaires were distributed, and 126 were processed and analyzed. The multiple linear regression and path analysis were employed to test the hypotheses. The results indicated that perceived ease-of-use and perceived security had a positive effect on the use of e-Filing, while perceived usefulness has no effect on the use of e-Filing. In addition, readiness of information technology did not mediate the relationships among the perceived ease-of-use, perceived usefulness, and perceived security on the use of e-Filing. This study implies that Directorate General of Taxes, as a provider of e-Filing services, may improve the quality of e-Filing, especially in terms of ease and security. It is because, based on the results of this study, both aspects have been empirically proven to be able to increase intention to use e-Filing in reporting the annual notification letter.
\end{abstract}

Keywords: Perceived Usefulness, Perceived Security, E-Filing

JEL Classification Code: C38, D70, M21

\section{Introduction}

Taxes are the primary source of income for most countries in the world, including Indonesia. The Ministry of Finance of the Republic of Indonesia, through a press conference describing the realization of the Revised State

\footnotetext{
*Acknowledgments:

The authors express their gratitude and appreciation to Assoc. Prof. Rizal Yaya and Dr. Udin for guiding and conducting the review process of this paper.

${ }^{1}$ First Author and Corresponding Author. Business and Economic Faculty, Universitas Muhammadiyah Yogyakarta, Indonesia [Postal Address: Jl. Brawijaya, Tamantirto, Kec. Kasihan, Yogyakarta, 55183, Indonesia] Email: afrizal@umy.ac.id

'Lecturer, Business and Economic Faculty, Universitas

Muhammadiyah Yogyakarta, Indonesia

'Lecturer, Business and Economic Faculty, Universitas

Muhammadiyah Yogyakarta, Indonesia

${ }^{4}$ Lecturer, Business and Economic Faculty, Universitas

Muhammadiyah Yogyakarta, Indonesia

(c) Copyright: The Author(s)

This is an Open Access article distributed under the terms of the Creative Commons Attribution Non-Commercial License (https://creativecommons.org/licenses/by-nc/4.0/) which permits unrestricted non-commercial use, distribution, and reproduction in any medium, provided the original work is properly cited.
}

Revenue and Expenditure Budget (APBN-P) in 2017, revealed that the recognition of tax revenue was $91 \%$ of the target of 2017 State Revenue and Expenditure Budget (APBN). As in previous years, the government could not achieve the targeted tax revenue mandated by the APBN. On the other hand, the number of taxpayers has increased from year to year, especially after the Policy and Tax Amnesty program. Therefore, the increase in the number of taxpayers was not enough to enable the tax authorities to reach the target of state revenue from the tax sector. The increasing number of taxpayers forced the government to make efforts to increase state revenue from taxes by updating the tax system, especially those related to tax administration. An update to the tax payment system was carried out by the Directorate General of Taxes (DJP) with the issuance of Decree of the Directorate General of Taxes Number KEP-88/ PJ/2014 containing the submission of Annual Notification Letter (SPT) carried out electronically, hereafter referred to as e-Filing. e-Filing is a method used by Personal Taxpayer (WPOP) and Corporate Taxpayer (WP Badan) in reporting SPT online and in real-time through the DJP website or Application Service Provider (ASP), commonly known as Electronic SPT Service Provider. The objectives of e-Filing 
are to facilitate tax compliance and to provide taxpayers service using Internet technologies and WWW. By using the e-Filing system, taxpayers can prepare, report, and pay their tax online (Hussein et al., 2010).

One of the main benefits felt by taxpayers (WP) when using e-Filing is that this system can be used anytime because it operates 24 hours a day and seven days a week, and it can be used anywhere by using the Internet network (Wibisono \& Toly, 2014). To service providers, E-filing minimizes their workload and operational cost due to the submission of tax returns in a paperless environment. It also reduces the cost of processing, storing, and handling of tax returns (Azmi \& Kamarulzaman, 2010). Another benefit is that data confidentiality and security can be guaranteed because a username and password provided by the DJP are required to operate e-Filing. The findings by Mustapha and Obid (2015) showed that professionals' effort in using e-tax Filing was determined by the perceived ease of use, compatibility and relative advantage, perceived innovativeness of information technology, and performance of the e-Filing system. The amount of the perceived benefits has led to more WPs moving from traditional SPT submissions to using e-Filing.

Moreover, here, the measured, strategic steps need to be taken by the government to educate the taxpayer (WPs) so that they are familiar with using E-Filing for submitting SPT. However, in addition to the implementation of various regulations requiring WP from certain circles to use e-Filing, socialization and education were also carried out to see the taxpayers' readiness in using e-Filing and to evaluate aspects of the technology used. By knowing how users' perceptions of e-Filing, for example, in terms of usability, ease of use, and security, DJP can adjust the application of e-Filing to match what is desired by WPs and increase intention to use e-Filing.

Several previous researchers have examined user perceptions of e-Filing, but the results of the study showed inconsistencies. The tax service quality is an essential determinant for the usage of the online tax system that provides relevance to the tax administration system (Mustapha \& Obid, 2015). Perceived ease-of-use explains the extent to which users can believe that in using technology, they do anything without the interference that becomes an obstacle for them. Research by Carter et al. (2011) showed that taxpayers' self-efficacy, the belief about what they can do with their technical abilities to execute e-file programs, had a significant influence on their intention to use the system. Lie and Sadjiarto (2013) and Novindra and Rasmini (2017) showed that perceived ease-of-use affected intention to use e-Filing. However, the results of the study contradict the research conducted by Rekayana (2016), discovering that perceived ease-of-use had a negative effect on intention to use e-Filing. Furthermore, several studies (Daryanto, 2017; Azmi et al., 2012; Yuni, 2017) uncovered that perceived ease-of-use did not affect intention to use e-Filing. Furthermore, perceived usefulness describes the extent to which users feel that by using the help of technology, they can improve their performance (Saripah et al., 2016). Wahyuni et al. (2015) and Rekayana (2016) discovered that perceived usefulness had a positive effect on intention to use e-Filing. This result disagrees with Novindra and Rasmini (2017), finding that perceived usefulness had a negative influence on intention to use e-Filing.

Apart from the users' perceived ease-of-use, perceived usefulness, and perceived security of e-Filing, aspects of information technology readiness can also affect intention of using e-Filing. Desmayanti (2012) and Riyadh, Alfaiza, and Sultan (2019) state that when users receive a technology well without any hesitation in operating it, it can be said that the technology is ready to use. Utami and Osesoga (2017) indicated that technology readiness had a positive effect on intention to use e-Filing. However, Salim (2013) revealed that technological readiness had no effect on intention to use e-Filing.

Based on the results of previous studies, this research seeks to empirically test the effect of perceived ease-of-use, perceived usefulness, and perceived security on intention to use e-Filing with information technology readiness as an intervening variable.

\section{Literature Review}

\subsection{Technology Acceptance Model (TAM)}

Technology Acceptance Model (TAM) is a theory describing the perception of technology users. Davis (1986) created this model to explain the effects of system characteristics on users of computer-based Technology Systems. TAM is the most widely used model for identifying factors contributing to technology acceptance. The theory suggests that, when users are presented with a new piece of technology, several factors influence their decision about how and when they will use the technology (Ardiansah, Chariri, Rahardja, \& Udin, 2020; Lindsay et al., 2011). The goal of TAM is to explain the determinants of general computer acceptance and be able to explain user behavior across a broad range of end-user computing technologies and user populations (Rondan-Cataluña et al., 2015). TAM was attempted to identify fundamental variables suggested by previous research. It specifies the relationships among perceived usefulness, perceived ease-of-use, attitude toward computer use, and intention to use technology (Teo et al., 2011).

This model shows that, when users are presented with new technology, some factors influence their decisions about how and when they will use them. The two most important factors are perceived usefulness and perceived ease-of-use. 
Thus, according to TAM, user acceptance of an information system depends on two factors, namely, perceived usefulness and perceived ease-of-use. Together, these factors determine attitudes toward the use of technology, where it can affect the behavioral intention to use, leading to the actual use of the system.

\subsection{Task Technology Fit (TTF)}

Task Technology Fit (TTF) is one of the theories of information systems with the behavioral approach, which describes the compatibility of tasks with information and communication technology (Goodhue \& Thompson, 1995; Ratna et al., 2018). Goodhue and Thompson (1995) explained that TTF is the theoretical basis for information systems research to examine issues related to the compatibility of tasks with information and communication technology. It means that TTF emphasizes that the accuracy of the implementation of tasks and information technology will support the performance of individuals in the company. Task-technology fit refers to matching the technology capabilities with the job requirements, namely, the ability of technology to support a task (Teo \& Men, 2008; Fu et al., 2019). Goodhue and Thompson (1995) proposed the TTF model, which extends the TAM by considering how a task affects the use of technology (Tam \& Oliveira, 2016).

\subsection{E-Filing}

The online tax filing system is present because the manual tax payment system is relatively complicated and time-consuming. Therefore, the online system is expected to be more effective and efficient in facilitating two-way communication in the tax payment service system (Rahman \& Mayasari, 2015). E-Filing generally consists of two words, electronic and filing. Electronic means using a computerized system, and filing is a form filling system. By using e-Filing, taxpayers can report their SPT anytime and anywhere, 24 hours a day, seven days a week. The data in the system will then be sent to the database of the Directorate General of Taxation through ASP (Yefni et al., 2018). Thus, e-Filing is a computer system that can be used to assist users in completing and submitting annual forms of SPT. The definition of e-Filing explained in the Tax General Regulation Number $\mathrm{KEP}-05 / \mathrm{PJ} / 2005$ is a method that can be used to submit and report annual SPT electronically, which is done online and in real-time through the Application Service Provider (ASP), a service company that DJP has been appointed to provide the e-Filing system. The objectives of e-Filing are to facilitate tax compliance and to give taxpayers service using Internet technologies and WWW. By using the e-Filing system, taxpayers can prepare, report, and pay their tax online (Hussein et al., 2011). Thus, the risk of late submission of SPT can be minimized if WPs report their SPT via e-Filing (Bandiyono $\&$ Husna, 2019). The adoption of e-Filing systems may seem to benefit taxpayers in many ways and also offer potential benefits to improve administrative commitments toward efficiency and quality of service delivery; however, citizens' understanding and acceptance of the electronic system is still minimal (Islam, 2012). Thus, e-Filing helps raise the level of compliance with submission requirements. The electronics system also opens new possibilities for disclosing data to the public and promoting better accountability and transparency (Koltyar \& Pop, 2019).

\section{Hypothesis Development}

\subsection{Perceived Ease toward Intention to Use e-Filing}

Perceived ease is related to how easy it is to access a technology system and its display. Based on the Technology Acceptance Model (TAM) model introduced by Davis (1986), users' perceived ease-of-use is one of the most critical factors in their acceptance of a system. Davis (1986) defined easeof-use as the extent to which users believe that by using a specific system, they will be free from effort. In other words, the more users feel a system is easy-to use, the higher their interest in using the system. The core assumptions in the TAM are that an individuals' use of technology is mediated by their acceptance of that technology, which in turn is determined by two cognitive factors, namely, perceived usefulness (PU) and perceived ease-of-use (PEOU) (Jones \& Kauppi, 2018). TAM was attempted to identify fundamental variables suggested by previous research. It specifies the relationships among perceived usefulness, perceived easeof-use, attitude toward computer use, and intention to use technology (Teo et al., 2011).

Likewise, if WPs feel that e-Filing is easy to use, then the level of intention to it is also increasing. A system can be said to be quality if it is designed to meet user satisfaction through the ease in using it; it is not only the ease to learn and use the system, but it also the ease of doing a job or task, where users will find it easier to work using the system than do it manually (Aryani et al., 2018; Le, Ngo, Trinh, \& Nguyen, 2020; Nguyen, 2020; Nguyen \& Luu, 2020; Phan, Nguyen, \& Bui, 2019). The ease, in this case, is not only limited to the ease of using e-Filing, but also related to whether this system eases them in completing SPT filling compared to doing it traditionally. Perceived ease-of-use influences the performance risk of the e-Filing system. A less complicated e-Filing system will minimize performance risks. Performance risks will be lowered only when taxpayers feel that the system is easy to use (Kamarulzaman \& Azmi, 2010). Some studies (Lie \& Sadjiarto, 2013), Novindra \& Rasmini, 2017; Riyadh, Sukoharsono, \& Baridwan, 2016; 
Zaidi et al., 2017) showed that perceived ease affected intention to use the system. Based on the results of both studies, it can be assumed that the easier e-Filing is used, the level of intention to use it will be higher, and vice versa, if e-Filing is difficult to use, the level of intention to use it will be lower. Therefore,

H1: Perceived ease has a positive effect on intention to use e-Filing.

\subsection{Perceived Usefulness toward Intention to Use e-Filing}

In addition to the perceived ease, based on the Technology Acceptance Model (TAM) model introduced by Davis (1986), perceived usefulness is also the most crucial factor in user acceptance of a system. The perceived usefulness of the system is related to the productivity and effectiveness of the system and its overall benefits to improve user performance. The core assumptions in the TAM are that individuals' usage of technology is mediated by their acceptance of that technology, which in turn is determined by two cognitive factors, perceived usefulness (PU) and perceived ease-of-use (PEOU) (Jones \& Kauppi, 2018). In other words, it is the extent to which a person believes that using a technology will improve the performance of his/her work. Therefore, the more useful a technology is, the higher the users' desire to use it.

Administratively, e-Filing may offer a potential benefit to the government because the process of a tax return by the citizens can be managed effectively via enabling technologies (Hussein et al., 2011). Related to e-Filing, if WPs feel that e-Filing is useful, it increases the level of intention to use it. The perception of utility directly affects intention to try and use the e-Filing system. If taxpayers feel the benefits, they will intend to use the system; otherwise, if they do not feel the benefits of the system, then they will not intend to use it (Aryani et al., 2018). Several studies (Rekayana, 2016; Zaidi et al., 2017) examined the effect of perceived usefulness on intention to use e-Filing. The results proved that perceived usefulness influenced intention to use e-Filing. Lymer et al. (2012) showed that e-Filing is a system having more immediate benefits for taxpayers with less complicated tax affairs, handled by small and medium-sized firms tax advisors, in general. Therefore,

H2: Perceived usefulness has a positive effect on intention to use e-Filing.

\subsection{Perceived Security toward Intention to Use e-Filing}

Perceived security is the users' perception related to the function and control of their personal data information in an online system. Users' perceived security of a system can influence their intention to use it. If users feel that the system they are using has a high risk, especially in terms of security, they are likely to avoid the system (Loewenstein et al., 2001). A user may view e-Filing favorably, but intention to use may be dampened by the risk perception of using it (Tan \& Foo, 2012).

The same thing applies to e-Filing systems. Therefore, DJP seeks to protect security by ensuring that third parties cannot access the privacy of taxpayers by providing usernames and passwords for each WP that has been registered with KPP Pratama to submit SPT online. The quality of the system is indicated by the fact that the e-Filing system can be used easily and conveniently by the corporate user in reporting taxes, and it does not require extra effort. Application Provider Services (ASP) server can be accessed quickly, easily, and conveniently; the e-Filing system can respond and deliver confirmation quickly; e-Filing system has security to protect the confidentiality of corporate user data; the process of sending data to the Directorate General of Taxes (Prawati \& Dewi, 2018). Salim (2013) and Mujiyani and Wahyuningtyas (2019) revealed that security had a positive effect on users to use e-Filing. Thus, it can be concluded that when WP has a perception that the e-Filing system is safe, it results in the higher the level of intention to use e-Filing. Therefore,

H3: Perceived security has a positive effect on intention to use e-Filing.

\subsection{Perceived Ease toward Intention to Use e-Filing with Information Technology Readiness as an Intervening Variable}

Information technology readiness can primarily be seen in individuals who will use the technology and from the readiness of the technology itself. Individual readiness is the extent to which the individual can accept new technology without any doubt on using it (Desmayanti, 2012). Most of the body of knowledge on electronic tax filing is centered on the issue of adoption. Such a heavy focus is understandable because usage is a critical criterion for assessing the success of innovation implemented (Koong et al., 2019). The tax e-Filing usage by the citizens was severely underused despite the availability and improvement of the technology. Thus, there is desperately a need to understand the determinants of tax e-Filing acceptability. Even though a lot of research had been conducted in searching for the answer, yet the problem of low tax e-Filing acceptability still lacks in the literature (Aziz, 2015). The e-government implementation is still not optimal due to the lack of system integration (Sofyani et al., 2020). The readiness of information technology can affect the thinking of its users. When users can easily accept and adapt 
to technology, the better the users' perception of technology, and their intensity in using the technology increases. While the readiness of technology means the availability of existing and enough software tools on these technologies so that they can process data quickly and accurately.

The issue of technology readiness is exceptionally essential, as the tax authorities around the world are embracing an e-government concept via e-tax services progressively. Taxpayers may turn to the tax officers for assistance when they have problems in accessing the e-tax services. Satisfactory taxpayers' e-tax service will hinge not only on the tax officers' inter-personal skills but also on their state of technology readiness (Muhammad, 2001). Daryanto (2017) discovered that perceived ease of use of e-Filing did not make taxpayers more frequent and interested in using e-Filing, but perceived ease-of-use had a negative influence on intention to use e-Filing. Daryanto (2017) assumed that it happened because the e-Filing system was unable to improve the efficiency and effectiveness of taxpayers in reporting taxes. Currently, not all taxpayers use e-Filing because they think that the use of computer systems in the reporting of the SPT is confusing and difficult than reporting manually. It is because many taxpayers do not understand the operation of e-Filing, and their ability to use e-Filing is still minimal (Khaddafi et al., 2018). To overcome this problem, DJP should improve the e-Filing system to be more ready to use. Increasing information technology readiness can undoubtedly improve efficiency and effectiveness in the use of technology. Therefore, it can be concluded that if WPs' perceived ease-of-use of e-Filing is accompanied by information technology that is ready to use, then intention to use e-Filing will also increase. Thus,

H4: Perceived ease has a positive effect on intention to use e-Filing with information technology readiness as an intervening variable.

\subsection{Perceived Usefulness toward Intention to Use e-Filing with Information Technology Readiness as an Intervening Variable}

The technology acceptance of individuals mediates their use of technology as the core assumptions in the TAM, which then specified by two cognitive factors, perceived usefulness (PU) and perceived ease-of-use (PEOU) (Jones \& Kauppi, 2018). Due to the tax return process of the citizens can be organized effectively through supporting technologies, administratively, e-Filing may offer a potential benefit to the government (Hussein et al., 2011). The intention to try and use the e-Filing system is directly affected by the perception of utility. If the taxpayers feel the benefits of an e-Filing system, they will have intention to use it; otherwise, if they do not feel the benefits of the system, then they will not intend to use it (Aryani et al., 2018). Agustina and Anim (2018) found that it did not influence intention to use e-Filing. The results of interviews conducted by researchers showed that it was caused by the lack of socialization received by users regarding the use and benefits of e-Filing. Therefore, the perception of the benefits of e-Filing was still low, and they chose not to use this new system. It exposes the unpreparedness of information in terms of individuals because WPs were still unable to accept and adapt to e-Filing technology. Therefore, it can be concluded that if WPs' perceived usefulness of e-Filing is accompanied by the individuals' readiness in accepting information technology, then intention to use e-Filing will also increase. Thus,

H5: Perceived usefulness has a positive effect on intention to use e-Filing with information technology readiness as an intervening variable.

\subsection{Perceived Security toward Intention to Use e-Filing Information Technology Readiness as an Intervening Variable}

Technology can be said to be good and ready if the system is risk-free or safe. According to Desmayanti (2012), information system security is the existence of management arrangements that can prevent, overcome, and protect information systems from actions that can be detrimental, such as unauthorized use and infiltration of various information held. A user may see e-Filing well, but intention to use it may be reduced by the risk perception of using this system (Tan \& Foo, 2012). In the previous hypothesis, the researchers assume that the more WPs feel that e-Filing is safe to use, the higher the level of use. However, Dewi and Susanti (2019) proved that security perception did not influence intention to use e-Filing. According to Dewi and Susanti (2019), it is because WPs felt that e-Filling could not guarantee data security, so they tended to avoid using it. The e-Filing system, which can be utilized easily and comfortably by the corporate users in reporting taxes and does not need extra effort, indicates the quality of the system. Application Provider Services (ASP) server can be accessed quickly, easily, and conveniently; e-Filing system can respond and deliver confirmation quickly; e-Filing system has security to protect confidentiality of corporate user data; the process of sending data to the Directorate General of Taxes (Prawati \& Dewi, 2018). Information quality and service quality of the website have a significant influence on taxpayers' intention to use online tax filling. Many taxpayers are not willing to utilize e-Filing because of the lack of trust on the website or the complexity of the system (Lu \& Nguyen, 2016).

It illustrates the unpreparedness of e-Filing information technology. Therefore, it can be concluded that if WPs' perceived security of e-Filing is accompanied by information 
technology readiness, intention to use e-Filing will also increase. Thus,

H6: Perceived security has a positive effect on intention to use e-Filing with information technology readiness as an intervening variable.

\section{Methodology}

Research data were collected by distributing questionnaires directly to respondents. As for the technique used in sampling, it was a purposive sampling technique, which was the determination of samples with specific criteria. The sampling criteria in the study were WP individuals in the Semarang City area, WP individuals who were required to use e-Filing in the submission of Annual Income Tax Returns, and WP Individuals form the 1770S, namely the Civil Servants Taxpayers, Indonesian National Armed Forces, and State Police of the Republic of Indonesia.

\subsection{Measurements}

Intention is a tendency that someone must choose to do or not do a job. The intention to use e-Filing was measured using two indicators created by Desmayanti (2012). Perceived ease, according to Davis (1986), is the extent to which users believe that by using a particular system, they will be free from effort. To measure this variable, six statement items would be used. It was made by Desmayanti (2012) related to respondents' perceived ease of use of e-Filing in the online SPT filling process.

Perceived usefulness, defined by Davis (1986), is the subjective perception of users where they believe that using certain technologies can improve the performance of their work. To measure this variable, six statement items would be employed; Saripah et al. (2016) proposed it regarding respondents' perceived usefulness of e-Filing in the online SPT filling process. Perceived security perception is related to the extent to which users believe that when they use a system, their security will be guaranteed (Firmawan $\&$ Marsono, 2009). To measure security perception, six statements were utilized. It was developed by Desmayanti (2012) concerning respondents' perceived security of using e-Filing in the online SPT filling process.

The information technology readiness means that individuals, in this case, are ready to accept the development of existing technology, including the emergence of e-Filing systems. To measure the WPs' information technology readiness variable, it employed three indicators related to information technology readiness by Desmayanti (2012). Respondents were then asked to determine the importance of each item from each variable using a five-point Likert scale.

\subsection{Hypothesis Testing}

Hypothesis testing was done using multiple linear regression and path analysis. Testing the relationship between the independent and dependent variables was conducted using the significance of 0.05 . If the significance value $<0.05$, the hypothesis is accepted. Moreover, path interpretation was employed to test the intervening variable. This test was carried out by looking at the significance value. If the value shows $\operatorname{sig}<0.05$, then a comparison between the standardize coefficient multiplication of the indirect effect of each variable with the square of the standardized coefficient of the direct effect is conducted. If the result of multiplication of the standardized coefficient of the indirect effect $\geq$ the square of the standardized coefficient of the direct effect, then intervening variable can be accepted.

\section{Result and Discussion}

The sample in this study was the WP OP, which consisted of Civil Servants Taxpayers, Indonesian National Armed Forces, and State Police of the Republic of Indonesia spread in Semarang City. Questionnaires were distributed on December 11, 2018, to January 18, 2019. Researchers distributed 150 copies of questionnaires to respondents. Respondents returned 131 questionnaires, but five people did not complete both personal data and questions in the questionnaire. Thus, the number of questionnaires used in the analysis was 126 pieces. Table 1 presents the response rates of the respondents to the distribution of the questionnaire, and Table 2 shows descriptive statistics of all the variables involved in this study.

Before testing the hypothesis, the validity and reliability tests were first performed. The results of the validity test showed that all $p$-value values of each question item for the research variable were smaller than 0.05 . It means that all items of questions used for this study were valid, and the data obtained could be used entirely. While the reliability test results showed the value of Cronbach's alpha on the variables of perceived ease, perceived usefulness, perceived security, information technology readiness, and intention to use e-Filing were higher than 0.7. Thus, all the above variables were said to be reliable.

Table 1: Analysis of Questionnaires Return

\begin{tabular}{|l|c|c|}
\hline Questionnaire & Number & Percent (\%) \\
\hline Amount distributed & 150 & 100.00 \\
\hline Amount returned & 131 & 87.33 \\
\hline Filled incomplete & 5 & 8.67 \\
\hline Total & 126 & 78,67 \\
\hline
\end{tabular}


Table 2: Descriptive Test Results

\begin{tabular}{|l|c|c|c|c|c|c|}
\hline Variable & N & Min & Max & Sum & Mean & Std. Deviation \\
\hline Intention to use e-Filing & 126 & 4 & 10 & 1086 & 8.62 & 1.350 \\
\hline Perceived Ease & 126 & 13 & 30 & 3095 & 24.56 & 3.479 \\
\hline Perceived Usefulness & 126 & 14 & 30 & 3287 & 26.09 & 3.289 \\
\hline Perceived Security & 126 & 9 & 25 & 2539 & 20.15 & 3.134 \\
\hline Information Technology Readiness & 126 & 3 & 15 & 1595 & 12.66 & 1.968 \\
\hline
\end{tabular}

Table 3: Results of Multiple Linear Regression Test, Regression Models 1

\begin{tabular}{|l|c|c|c|c|c|}
\hline Variable & Code & Direction & Coefficient & t-count & Sig. \\
\hline Perceived Ease & $\mathrm{H}_{1}$ & + & 0.456 & 5.371 & $0.000^{*}$ \\
\hline Perceived Usefulness & $\mathrm{H} 2$ & + & 0.115 & 1.237 & 0.218 \\
\hline Perceived Security & $\mathrm{H}_{3}$ & + & 0.376 & 4.389 & $0.000^{*}$ \\
\hline
\end{tabular}

Dependent Variable: Intention to use e-filing * is significant at alpha 0.05

Table 4: Results of Multiple Linear Regression Test, Regression Models 2

\begin{tabular}{|l|c|c|c|c|c|}
\hline Variable & Code & Direction & Coefficient & t-count & Sig. \\
\hline Perceived Ease & $\mathrm{H}_{4}$ & + & -0.084 & -0.744 & 0.458 \\
\hline Perceived Usefulness & $\mathrm{H}_{5}$ & + & 0.402 & 3.395 & 0.001 \\
\hline Perceived Security & $\mathrm{H}_{6}$ & + & 0.216 & 1.922 & 0.057 \\
\hline
\end{tabular}

Dependent Variable: Intention to use e-filing * is significant at alpha 0.05

Then, a classic assumption test consisted of tests of normality, multicollinearity, and heteroscedasticity was carried out. The results of the normality test using the Kolmogorov Smirnov test found that the value of sig. for the first model was $0.350>$ alpha $(0.05)$, and sig. for the second model was $0.092>$ alpha (0.05). It indicated that the data were normally distributed. Besides, multicollinearity test results through tolerance values on all independent variables were more than 0.1 , and for VIF values, it was less than 10. Thus, it could be concluded that there was no multicollinearity between each independent variable. At last, the heteroscedasticity test with the Spearman Range Test showed that all independent variables of the two models did not affect the Unstandardized Residual value. It was because it had a significant value higher than $5 \%$ or 0.05 . The conclusion from the Spearman Range Test above was that there were no indications of heteroscedasticity in either the first regression model or the second regression model.

\subsection{The Effect of Perceived Ease on Intention to Use E-Filing}

Table 3 shows that the variable of perceived ease has a regression coefficient (beta) of 0.456 and sig. of 0,000 . The significance level of perceived ease variables was smaller than alpha $(\alpha) 0.05$. Thus, it could be concluded that perceived ease had a positive effect on intention to use e-Filing. Therefore, the first hypothesis or H1 was supported. It showed that the higher the perceived ease of e-Filing users toward intention to use it, the higher the number of WPs used e-Filing. This research supports previous research (Rekayana, 2016; Novindra \& Rasmini, 2017) stating that perceived ease affected intention to use e-Filing.

\subsection{The Effect of Perceived Usefulness on Intention to Use E-Filing}

Table 3 shows that the perceived usefulness variable has a regression coefficient (beta) of 0.115 and a sig value of 0.218 . The significance level of the perceived usefulness variable was higher than alpha $(\alpha) 0.05$. Thus, it could be concluded that the perceived usefulness did not affect intention to use e-Filing. Therefore, the second hypothesis or $\mathrm{H} 2$ was not supported.

\subsection{The Effect of Perceived Security on Intention to Use E-Filing}

Table 3 shows that the perceived security variable has a regression coefficient (beta) of 0.376 and a sig value 
of 0,000 . The significance level of the perceived security variable was smaller than the alpha $(\alpha) 0.05$. Therefore, it could be concluded that perceived security had a positive effect on intention to use e-Filing. Thus, the third hypothesis or H3 was supported. It shows that the higher the perceived security of e-Filing users, the higher the number of WPs who it. This study supports research (Desmayanti, 2012; Wahyuni et al., 2015), discovering that perceived security had a positive effect on intention to use e-Filing.

\subsection{The Relationship between Perceived Ease on Intention to Use E-Filing with Information Technology Readiness}

Information technology readiness is said to mediate the effect of perceived ease on intention to use e-Filing if the significance value of perceived ease toward intention to use e-Filing is $<0.05$. Also, the comparison of indirect effects, namely the standardize coefficient of perceived ease to information technology readiness ( $\rho 4)$, multiplied by the standardize coefficient of the information technology readiness to intention to use e-Filing $(\rho 7)$, greater or equal to the square of the direct influence of perceived ease of e-Filing $(\rho 1)$, or can be written as $\left(\rho 4^{*} \rho 7\right) \geq \rho 1^{2}$.

It was known in Table 4 that the significance value of perceived ease toward information technology readiness was $0.458>0.05$ (Alpha). It could be concluded that the information technology readiness was not an intervening variable mediating the perceived ease toward intention to use e-Filing. Thus, the fourth hypothesis (H4) was not supported.

\subsection{The Relationship between Perceived Usefulness on Intention to Use E-Filing with Information Technology Readiness}

Information technology readiness is said to mediate the effect of perceived usefulness variables on intention to use e-Filing if the significance value of perceived usefulness to intention to use e-Filing is $<0.05$. Besides, the comparison of indirect influence, namely, the standardize coefficient of perceived usefulness to the information technology readiness $(\rho 5)$, multiplied by the standardize coefficient of information technology readiness to intention to use e-Filing ( $\rho 7)$ is higher than the square of the direct influence, i.e., the perceived ease toward e-Filing intention $(\rho 2)$, or can be written as $\left(\rho 5^{*} \rho 7\right) \geq \rho 2^{2}$.

It was known in Table 4 that the significance value of perceived usefulness to the information technology readiness was $0.001<0.05$ (Alpha). In addition, the results of $\left(\rho 5^{*} \rho 7\right)$ or $(0.402 *-0.256)$ were -0.10291 , while the results of $\rho 1^{2}$ or $(0.115)^{2}$ were 0.013225 . Based on the above calculations, it could be concluded that $\left(\rho 5^{*} \rho 7\right)<\rho 2^{2}$ or -0.10291
$<0.013225$. It indicated that the information technology readiness was not an intervening variable mediating the perceived usefulness toward intention to use e-Filing. Thus, the fifth hypothesis (H5) was not supported.

\subsection{The Relationship between Perceived Security on Intention to Use E-Filing with Information Technology Readiness}

Information technology readiness is said to mediate the effect of perceived security variables on intention to use e-Filing if the significance value of perceived security on intention to use e-Filing is $<0.05$. Besides, the comparison of indirect effects, namely standardize coefficient from perceived security to information technology readiness ( $\rho 4)$ multiplied by the standardized coefficient from the information technology readiness to intention to use e-Filing ( $\rho 7)$ is higher than the square of the direct influence, namely, the perceived ease to intention to use e-Filing ( $\rho 1)$, or can be written as $\left(\rho 6^{*} \rho 7\right) \geq \rho 1^{2}$.

It was known in Table 4 that the significance value of perceived security on the information technology readiness was $0.057>0.05$ (Alpha). It could be concluded that the information technology readiness was not a variable mediating perceived security on intention to use e-Filing. Therefore, the sixth hypothesis (H6) was rejected.

\section{Conclusion}

This study concluded that perceived ease and perceived security positively influenced intention to use e-filing. In contrast, perceived usefulness did not affect intention to use e-filing. Besides, the information technology readiness as an intervening variable could not mediate the effect of perceived usefulness, ease, or security on intention to use e-Filing.

This study implies that DJP, as a provider of e-filing services, can improve the quality of e-Filing, especially in terms of ease and security. It is because, based on the results of this study, both aspects have been empirically proven to be able to increase intention of WPs to use e-Filing in reporting the annual SPT.

There are some limitations in this study, including the respondents who were only WP OP that had been required to use e-Filing and only involved Civil Servants Taxpayers, Indonesian National Armed Forces, and State Police of the Republic of Indonesia in Semarang City. Besides, the questionnaire used as a data collection method was closed questions, aiming to find out the respondents' opinions on each research variable, causing respondents unable to provide additional information on their responses. In connection with the existing limitations, the researchers have some suggestions for further research. The first is adding 
respondents who are not only limited to WP OP that has been required to use e-Filing but WP OP as a whole and come from various cities in Indonesia. Moreover, future research will be better if it develops research models and research instruments, as well as involving interviewing respondents and experts.

\section{References}

Agustina, \& Anim. (2018). Influence of Perception of Usability, Perception of Ease and Satisfaction on the Use of Taxpayer E-filing (Study of Civil Servants in IAIN Surakarta Environment). Doctorate Dissertation, IAIN Surakarta, Kabupaten Sukoharjo, Indonesia. [Indonesian]

Ardiansah, M. N., Chariri, A., Rahardja, S., \& Udin, U. (2020). The effect of electronic payments security on e-commerce consumer perception: An extended model of technology acceptance. Management Science Letters, 10(7), 1473-1480. doi: $10.5267 /$ j.msl.2019.12.020

Aryani, R. A. I., Herwanti, R. T., \& Basuki, P. (2018). The Effect of Perception of Use, Ease, Security and Confidentiality to Use E-Filing (Study in the Tax Office Pratama Raba Bima). International Journal of Scientific Research and Management, 6(4), 294-304. https://doi.org/10.18535/ijsrm/v6i4.em08

Aziz, S. A. (2015). The determinants of tax e-filing among tax preparers in Malaysia. World Journal of Social Sciences, 2(3), 182-188.

Azmi, A. A. C., \& Kamarulzaman, Y. (2010). Adoption of tax e-filing: A conceptual paper. African Journal of Business Management, 4(5), 599-603.

Azmi, A. A. C., Kamarulzaman, Y., \& Hamid, N. H. A. (2012). Perceived risk and the adoption of tax e-filing. World Applied Sciences Journal, 20(4), 532-539. https://doi.org/10.5829/ idosi.wasj.2012.20.04.2403

Bandiyono, A., \& Husna, M. C. (2019). Service E-Filing and E-Biling to Increase Tax Compliance and Acceptance. Politeknik Keuangan Negara STAN, 1(2). [Indonesian]

Carter, L., Shaupp, C. L., Hobbs, J., \& Campbell, R. (2011). The role of security and trust in the adoption of online tax filing. Transforming Government: People, Process and Policy, 5(4), 303-318. https://doi.org/10.1108/17506161111173568

Daryanto. (2017). Factors Affecting the Use of E-Filing in Individual Taxpayers in West Jakarta. Jurnal Muara Ilmu Ekonomi Dan Bisnis, 1(1). [Indonesian]

Davis, F. D. (1986). A technology acceptance model for empirically testing new end-user information systems: Theory and results. Doctoral dissertation, Cambridge, MA: Massachusetts Institute of Technology.

Desmayanti. (2012). Factors that influence the use of e-filing facilities by taxpayers as a means of submitting periodic tax returns online and real time (empirical studies in the city area of Semarang). Indonesian Accounting Research Journal, 1(1). [Indonesian]
Dewi, \& Susanti. (2019). Perception of Permanent Lecturers in West Jakarta and Tangerang Regions Against the Use of E-filing. Journal of Economics, 24(1). [Indonesian]

Fu, J., Shang, R. A., Jeyaraj, A., Sun, Y., \& Hu, F. (2019). Interaction between task characteristics and technology affordances: Tasktechnology fit and enterprise social media usage. Journal of Enterprise Information Management, 33(1), 1-22. https://doi. org/10.1108/JEIM-04-2019-0105

Goodhue, D. L., \& Thompson, R. L. (1995). Task-Technology Fit and Individual Performance. MIS Quarterly, 19(2), 213-236.

Hussein, R., Mohamed, N., Ahlan, A. R., \& Mahmud, M. (2011). E-government application: An integrated model on G2C adoption of online tax. Transforming Government: People, Process and Policy, 5(3), 225-248. https://doi. org $/ 10.1108 / 17506161111155388$

Hussein, R., Mohamed, N., Ahlan, A. R., Mahmud, M., \& Aditiawarman, U. (2010). An integrated model on online tax adoption in Malaysia. Proceedings of the European, Mediterranean and Middle Eastern Conference on Information Systems: Global Information Systems Challenges in Management, EMCIS 2010, January 2010.

Islam, A. (2012). Factors affecting user satisfaction in the Malaysian income tax e-filing system. African Journal of Business Management, 6(21), 6447-6455. https://doi.org/10.5897/ ajbm11.1689

Jones, A. B., \& Kauppi, K. (2018). Examining the antecedents of the technology acceptance model within e-procurement. International Journal of Operations and Production Management, 38(1), 22-42. https://doi.org/10.1108/ IJOPM-06-2015-0346

Kamarulzaman, Y., \& Azmi, A. A. C. (2010). Tax E-filing Adoption in Malaysia: A Conceptual Model. Journal of E-Government Studies and Best Practices, 2010, 1-6.

Khaddafi, M., Aspan, H., Heikal, M., Wahyuddin, Falahuddin, \& ZatinHumaira. (2018). Effect of Perception of Facilities, Intensity of Conduct, and Satisfaction of Tax Payers to Submission of Letter by E-Filing Notice on Tax Service. 1, 583-587. https://doi.org/10.1108/978-1-78756-793-1-00001

Koong, K. S., Bai, S., Tejinder, S., \& Morris, C. (2019). Advancements and forecasts of electronic tax return and informational filings in the US. International Journal of Accounting and Information Management, 27(2), 352-371. https://doi.org/10.1108/IJAIM-06-2018-0072

Le, H. B. H., Ngo, C. T., Trinh, T. T. H., \& Nguyen, T. T. P. (2020). Factor Affecting Customers' Decision to Use Mobile Banking Service: A Case of Thanh Hoa Province, Vietnam. Journal of Asian Finance, Economics and Business, 7(2), 205-212. https:// doi.org/10.13106/jafeb.2020.vol7.no2.205

Lie, I., \& Sadjiarto, A. (2013). Factors that influence Taxpayer Behavior Interest in Using e-filing. Tax \& Accounting Review, $3(2), 1-15$.

Lindsay, R., Jackson, T. W., \& Cooke, L. (2011). Adapted technology acceptance model for mobile policing. Journal of 
Afrizal TAHAR, Hosam Alden RIYADH, Hafiez SOFYANI, Wahyu Eko PURNOMO/

Journal of Asian Finance, Economics and Business Vol 7 No 9 (2020) 537-547

Systems and Information Technology, 13(4), 389-407. https:// doi.org/10.1108/13287261111183988

Loewenstein, G. F., Weber, E. U., Hsee, C. K., \& Welch, N. (2001). Risk as feelings. Psychological Bulletin, 127(2), 267-286. https://doi.org/10.1037/0033-2909.127.2.267

Lu, N. L., \& Nguyen, V. T. (2016). Online Tax Filing-E-Government Service Adoption Case of Vietnam. Modern Economy, 7(12), 1498-1504. https://doi.org/10.4236/me.2016.712135

Lymer, A., Hansford, A., \& Pilkington, K. (2012). Developments in tax e-filing: Practical views from the coalface. Journal of Applied Accounting Research, 13(3), 212-225. https://doi. org/10.1108/09675421211281290

Muhammad, I. (2001). Taxation and Technology: Technology Readiness of Malaysian Tax Officers in Petaling Jaya Branch. Journal of Financial Reporting \& Accounting, 4(1), 147-163.

Mujiyani, \& Wahyuningtyas. (2019). Analysis of Factors that Influence the Use of E-filing for Individual Taxpayers (Empirical Study of Taxpayers at KPP Surakarta). Proceeding of The Urecol, 169-179. [Indonesian]

Mustapha, B., \& Obid, S. N. B. S. (2015). Tax Service Quality: The Mediating Effect of Perceived Ease of Use of the Online Tax System. Procedia - Social and Behavioral Sciences, 172, 2-9. https://doi.org/10.1016/j.sbspro.2015.01.328

Nguyen, O. T. (2020). Factors Affecting the Intention to Use Digital Banking in Vietnam. Journal of Asian Finance, Economics and Business, 7(3), 303-310. https://doi.org/10.13106/jafeb.2020. vol7.no3.303

Nguyen, X. T., \& Luu, Q. K. (2020). Factors Affecting Adoption of Industry 4.0 by Small- and Medium-Sized Enterprises: A Case in Ho Chi Minh City, Vietnam. Journal of Asian Finance, Economics and Business, 7(6), 255-264. https://doi. org/10.13106/jafeb.2020.vol7.no6.255

Novindra, N. P. B., \& Rasmini, N. K. (2017). The Influence of Ease of Use, Perceived Use, and Computer Self Efficacy on Interest in Using E-SPT. E-Journal of Accounting, 19(2), 1116-1143.

Prawati, L. D., \& Dewi, M. S. (2018). The analysis of factors which affect corporate taxpayer's interest using e-filing system. Pertanika Journal of Social Sciences and Humanities, 26(T), 279-288.

Phan, D. T. T., Nguyen, T. T. H., \& Bui, T. A. (2019). Going beyond Border? Intention to Use International Bank Cards in Vietnam. Journal of Asian Finance, Economics and Business, 6(3), 315-325. https://doi.org/10.13106/jafeb.2019.vol6.no3.315

Rahman, D. S., \& Mayasari, T. (2015). The Effect Of Inovation Attrubites and Taxpaye's Experience On The Interest Of The Use Of Online Tax Filling System On Individual Tax Payers In Surabaya. The Indonesian Accounting Review, 5(1), 77-86. http://dx.doi.org/10.14414/tiar.v5i1.492.

Ratna, S., Astuti, E. S., Utami, H. N., Rahardjo, K., \& Arifin, Z. (2018). Characteristics of tasks and technology as a driver of task-technology fit and the use of the hotel reservation information system. VINE Journal of Information and
Knowledge Management Systems, 48(4), 579-595. https://doi. org/10.1108/VJIKMS-05-2018-0035

Rekayana. (2016). Perception of Benefit, Ease, Satisfaction of Personal Taxpayers in the Implementation of the E-Filing System against Compliance with Annual Tax Reporting. Jurnal Ilmiah Mahasiswa FEB, 4(2). [Indonesian]

Riyadh, H. A., Sukoharsono, E. G., \& Baridwan, Z. (2016). E-banking Implementation and Technology Acceptance in the Rafidain and Rasheed Banks in Iraq: an Employee Perspective. The International Journal of Accounting and Business Society, 23(2), 87-113.

Riyadh, H. A., Alfaiza, S. A., \& Sultan, A. A. (2019). The Effects of Technology, Organizational, Behavioral Factors towards Utilization of E-Government Adoption Model by Moderating Cultural Factors. Journal of Theoretical and Applied Information Technology, 97(8), 2142-2165.

Rondan-Cataluña, F. J., Arenas-Gaitán, J., \& Ramírez-Correa, P. E. (2015). A comparison of the different versions of popular technology acceptance models a non-linear perspective. Kybernetes, 44(5), 788-805. https://doi. org/10.1108/K-09-2014-0184

Salim. (2013). Factors That Influence the Use of E-filing Facilities by Taxpayers as a means of Submission of Annual Tax Returns in Oline and Realtime (Empirical Study of Corporate Taxpayers at KPP Madya, Central Jakarta). Universitas Bung Hatta, Sumatera Barat, 6(2). [Indonesian]

Saripah, Putri, \& Darwin. (2016). The Influence of Trust, Benefit Perception, Risk Perceion, and Satisfaction of Taxpayers on the Use of E-Filing for Individuals Taxpayers in KPP Pratama Pekanbaru, Handsome in 2015. Jurnal Akuntansi Dan Ekoomika, 6(2). [Indonesian]

Sofyani, H., Riyadh, H. A., \& Fahlevi, H. (2020). Improving service quality, accountability and role of information technology governance Improving service quality, accountability and transparency of local government: The intervening role of information technology governance. Cogent Business \& Management, 7(1), 1-20. https://doi.org/10.1080/23311975.20 20.1735690

Tam, C., \& Oliveira, T. (2016). Performance impact of mobile banking: using the task-technology fit (TTF) approach. International Journal of Bank Marketing, 34(4), 434-457. https://doi.org/10.1108/IJBM-11-2014-0169

Tan, T. H., \& Foo, Y.-F. (2012). Predicting Taxpayers' Intentions of Adopting Electronic Tax-Filing (E-Filing) In Malaysia. Journal of Accounting Business and Management, 19(2), 59-71. https:// doi.org/10.1017/CBO9781107415324.004

Teo, T. S. H., \& Men, B. (2008). Knowledge portals in Chinese consulting firms: A task-technology fit perspective. European Journal of Information Systems, 17(6), 557-574. https://doi. org/10.1057/ejis.2008.41

Teo, T., Ursavaş, Ö. F., \& Bahçekapili, E. (2011). Efficiency of the technology acceptance model to explain pre-service teachers' intention to use technology: A Turkish study. 
Campus-Wide Information Systems, 28(2), 93-101. https://doi. org/10.1108/10650741111117798

Utami, A., \& Osesoga, M. (2017). Factors That Influence the Use of Personal Taxpayer E-filing. Ultimaccounting: Journal of Accounting, 9(2), 15-32. https://doi.org/10.31937/akuntansi.v9i2.727.

Wahyuni, R., Ritonga, K., \& Rusli, R. (2015). The Influence of Perception of Usefulness, Slavery, Security, and Confidentiality, and Speed on Behavioral Intensity in the Use of E-Filing). Student Online Journal, 2(2), 1-15. [Indonesian]

Wibisono, L. T., \& Toly, A. A. (2014). Analysis of Factors Affecting Taxpayer Interest in Using E-filing in Surabaya. Tax \& Accounting, 4(1), 1-15.
Yefni, Y., Murniati, S., Zifi, M. P., \& Yuliantoro, H. R. (2018). What Are the Motivation of Taxpayers in Using E-Filling Information Systems? Jurnal Akuntansi Multiparadigma, 9(3), 510-525. https://doi.org/10.18202/jamal.2018.04.9030

Yuni. (2017). Influence of Perception of Usability, Ease of Use, User Satisfaction, Security and Confidentiality, and Comfort of Taxpayers on the Use of E-Filing (Case Study on Individual Taxpayers in KPP Pratama Klaten). Doctoral dissertation, Surabaya, Indonesia: Universitas Widya Darma. [Indonesian]

Zaidi, S. K. R., Henderson, C. D., \& Gupta, G. (2017). The moderating effect of culture on e-filing taxes: evidence from India. Journal of Accounting in Emerging Economies, 7(1), 134-152. https://doi.org/10.1108/jaee-05-2015-0038 